\title{
Cytotaxonomy of the monopodial orchids of the African and Malagasy regions
}

\author{
J. C. Arends \& F. M. Van der Laan \\ Department of Plant Taxonomy and Plant Geography, Agricultural University, Gen. Foulkesweg 37,6700 \\ ED Wageningen, The Netherlands
}

\begin{abstract}
The three subtribes which are recognized within the tribe Vandeae are represented in the tropical African and Malagasy regions. All taxa of the Vandeae have a monopodial growth habit. The first subtribe, Sarcanthinae, is mainly Asian-Australasian, but a few of its species occur in Madagascar and in Africa. The other two subtribes, Angraecinae and Aerangidinae, are both represented in the latter two regions. The Angraecinae is characterized by the presence of a short rostellum, but this is elongated in the Aerangidinae. According to earlier authors there is a correlation between presence of the short rostellum and a basic chromosome number of $x=19$ in the Angraecinae, and between the presence of an elongated rostellum and a basic number of $x=25$ in the Aerangidinae.

The results presented in this paper are placed in perspective with the chromosome numbers recorded by other authors. From the resulting chromosome number survey it appears that only part of the Angraecinae (Aeranthes, several species of Angraecum. Cryptopus and Jumellea) have a basic number of $\mathrm{x}=19$; some members of the Angraecinae (other species of $A$ ngraecum) were found to have a basic number of $\mathrm{x}=21,24$ and 25.
\end{abstract}

The Aerangidinae is not characterized by a single basic number of $x=25$ but by a series ranging from $x=$ 23 to $x=27$, of which $x=23,24$ and 25 are the most frequent. The genus Calyptrochilum, although having a distinctly elongated rostellum, is characterized by a basic number of $x=19$ and its position within the Aerangidinae may therefore be questioned.

The present evidence suggests that too much weight has been attributed to a single character, i.e. the shape of the rostellum, in distinguishing the two subtribes. As there appear to be two groups according to basic number in Angraecum, it appears questionable whether Angraecum, as presently conceived, is a 'natural' genus. Further chromosomal and other taxonomic evidence is needed to substantiate the challenge to the present views in respect of Angraecum.

Taxa with $x=19$ appear to be frequent in Madagascar and the other islands in the Indian Ocean, whereas taxa with $x=21$ to 27 mainly occur on the African continent. The predominance of $x=19$ in the Malagasy flora suggests a link with the monopodial taxa of the Asian and Australasian floras, which are exclusively based on $x=19$.

\section{Introduction}

This paper is a continuation of our previous paper (Arends et al., 1980) which deals, among other things, with the somatic chromosome numbers of the 'angraecoid' orchids of Africa. The taxa in this group of orchids, which are characterized by a monopodial growth habit, occur in Africa but also on the islands of Madagascar, the Mascarenes, the Comores and the Seychelles. 
Schlechter $(1918,1926)$ divided the 'angraecoid' orchids into two groups: the first group (Angraecinae) is characterized by a non-elongated and deeply cleft rostellum, whereas this structure is elongated in the second group (Aeranginae). Schlechter's view was accepted by Summerhayes (1966) who gave both groups the rank of subtribes, naming them Angraecinae and Aerangidinae respectively. According to his latin diagnosis the Angraecinae is not only characterized by a short rostellum, but also by a basic chromosome number of $x=19$. The Aerangidinae in contrast is characterized by an elongated rostellum and a basic number of $x=25$. Evidence for these character combinations was presented by Jones (1967).

Our earlier publication showed that the correlation proposed by Summerhayes cannot be maintained for all species, as presently allocated to either of the two subtribes. The evidence which was accumulated also indicated that the chromosome numbers of the 'angraecoid' orchids are not solely multiples of $x=19$ or 25 because deviating numbers such as $2 \mathrm{n}=46$ were found (Arends et al., 1980).

This paper presents additional evidence that in particular in the Angraecinae the correlation between rostellum shape and basic number has to be refuted, and that several basic numbers occur in each of the two subtribes.

\section{Material and methods}

\section{Methods}

Permanent slides were made according to the method described by Arends et al. (1980). For future reference they are kept at this department (WAG). Their numbers are mentioned in the sixth column of Table 1.

The preparation of good slides in the first place depends on root tips with actively dividing meristems. The epiphytic monopodial orchids however, produce limited numbers of such root tips. As frequent sampling of the tips is harmful to the plants, it should be done with care to avoid damage.

Altogether, this means that the karyotype analysis of this group of orchids is a matter of patience and time. Many of the species are rare in nature as well as in cultivation, and it will be a long time before the 'angraecoid' orchids are analysed completely.

\section{Material}

The plants analysed for their karyotypes are listed in the first column of Table 1 . They are part of the living plant collection of this department. Many of the specimens were collected by department members, but Mr. C. Bruin at Zwaagdijk, Dr. D. Mulder, Dr. W. G. Sombroek, both at Wageningen, and Mr. J. M. Wubben at Hollandse Rading also kindly donated plants collected in Africa. Other plants were acquired from the botanical gardens at Copenhagen, Frankfurt and Munich.

In most cases the provenance of the specimens is known. A general indication of their provenance is given in the last column of Table 1, but more detailed information is recorded on the labels of the preserved plants (dried and alcohol) which are kept at WAG. Colour slides of the flowering plants are also available at WAG. In those cases where no voucher material is cited in the seventh column of Table 1, the specimens have not yet flowered in the collection, but could be identified on the basis of vegetative characters. Vouchers will be made as soon as they flower.

The plants have been identified by the authors.

\section{Results and comments}

The observed somatic chromosome numbers are presented in the second column of Table 1 . Well spread metaphase plates, which are essential for conclusive counts were rare. Metaphase plates showing for example $2 n=48,2 n=50$ or $2 n=52$ chromosomes are very similar in appearance, particularly when the chromosomes are small. Moreover, the chromosomes are usually 'sticky', hence the interpretation of metaphase plates is difficult. Apparently earlier investigators (Chardard, 1963; Jones, 1967) have had similar experiences; some of their records are to some degree erroneous or indicated by an approximate figure.

With respect to chromosome length there are differences and similarities between the taxa. Within certain limits the size of the chromosomes depends on their contraction. This means that the figures indicating the lengths of the shortest and longest chromosomes in the observed metaphase plates are approximate. It appears that with the present methods the differences in overall chromosome length between the various taxa are of limited 
Tahle I. Somatic chromosome numbers observed in monopodial orchids of the African and Malagasy regions.

\begin{tabular}{lllll}
\hline Taxa & $\begin{array}{l}\text { Chrom. } \\
\text { number } \\
(2 \mathrm{n})\end{array}$ & $\begin{array}{l}\text { Approx. Living Voucher } \\
\text { chrom. } \\
\text { length } \\
(\mu \mathrm{m})\end{array}$ & $\begin{array}{l}\text { Slant } \\
\text { number }\end{array}$ & \\
& & & $\begin{array}{l}\text { Plide } \\
\text { number }\end{array}$ \\
\hline
\end{tabular}

\begin{tabular}{|c|c|c|c|c|c|c|}
\hline \multicolumn{7}{|l|}{ Sarcanthinae } \\
\hline Acampe pachyglossa Rchb.f. & 38 & $1.0-2.5$ & $81-335$ & JK W 262 & 9- 62 & Mozambique \\
\hline \multicolumn{7}{|l|}{ Angraecinae } \\
\hline \multicolumn{7}{|l|}{ Angraecum } \\
\hline \multirow[t]{2}{*}{ A. aporoides Summerh. } & 48 & $1.0-1.7$ & $80-42$ & WALG 367 & $7-83$ & Principe \\
\hline & & & & Laan 181 & & \\
\hline A. calceolus Thouars & 38 & $1.0-2.0$ & $80-424$ & Laan 533 & $10-18$ & Madagascar \\
\hline A. caricifolium Perrier & 38 & $1.0-1.7$ & $80-431$ & Laan 394 & $10-16$ & Madagascar \\
\hline A. cultriforme Summerh. & 38 & $1.5-2.5$ & $82-62$ & Laan 506 & $10-35$ & Kenya \\
\hline A. doratophillum Summerh. & 92 & $1.0-2.0$ & $80-102$ & Laan 307 & $10-23$ & São Tomé \\
\hline$A$, erecrum Summerh. & 42 & $1.0-1.7$ & 80.267 & Laan 252 & $7-85$ & Kenya \\
\hline A. gabonense & 46 & $1.0-1.7$ & $81-264$ & Laan 526 & $8-93$ & Zaire \\
\hline A. leonis (Rchb.f.) Veitch & 38 & $1.5-3.0$ & $80-416$ & Laan 568 & 9: 88 & Madagascar \\
\hline A. pungens Schltr. & 46 & $1.0-1.5$ & $81-424$ & Laan 440 & $10-36$ & West Africa \\
\hline A. sesquipedale Thouars & 38 & $1.0-2.0$ & - & Laan 559 & $8-22$ & Madagascar \\
\hline \multicolumn{7}{|l|}{ Aeranthes } \\
\hline \multicolumn{7}{|l|}{ Cryptopus } \\
\hline C. elatus (Thouars) Ldl. & 76 & $1.0-2.5$ & & & $10-37$ & Madagascar \\
\hline \multicolumn{7}{|l|}{ Aerangidinae } \\
\hline \multicolumn{7}{|l|}{ Aerangis } \\
\hline A. brachycarpa (A. Rich.) Dur. \& Schinz & 50 & $1.0-2.5$ & $00-517$ & Laan 326 & $2-31$ & Cameroon \\
\hline A. calantha (Schitr.) Schltr. & 46 & $1.0-1.5$ & $80-395$ & L.aan 237 & $7-79$ & Zaire \\
\hline A. cirrata Schltr. & So & $1.0-2.0$ & $80-411$ & Laan 382 & $8-94$ & Madagascar \\
\hline A. cryptodon Rchb.f. & so & $1.0-1.5$ & $80-474$ & & $9-22$ & Madagascar \\
\hline A. kirkii (Rchb.f.) Schltr. & 52 & $1.0-2.0$ & $80-135$ & Laan 148 & $5-94$ & Kenya \\
\hline \multicolumn{7}{|l|}{ A. luteo-alba (K raenzl.) Schitr. var. } \\
\hline rhodosticta (Kraenzl.) J. Stewart & 42 & $1.0-1.7$ & $80-262$ & Laan 347 & 7- 87 & Kenya \\
\hline A. somalensis (Schltr.) Schltr. & 54 & $1.0-2.5$ & $80-42 I$ & Laan 419 & $9-39$ & Kenya \\
\hline A. ugandensis Summerh. & 50 & $1.0-1.5$ & $80-423$ & Laan 209 & $9-13$ & Kenya \\
\hline A. ugandensis Summerh. & 50 & $1.0-2.0$ & $81-449$ & & $9-89$ & Kenya \\
\hline \multicolumn{7}{|l|}{ Ancistrorhynchus } \\
\hline A. capiratus (Ldl.) Summerh. & 72 & $1.5-3.0$ & 750 & Burg 1248 & $7-99$ & Liberia \\
\hline A. capilalus (Ldl.) Summerh. & 72 & $1.5-3.0$ & $80-403$ & Laan 540 & $9-51$ & Zaire \\
\hline A. clandestinus (Ldl.) Schltr. & 48 & $1.5-3.0$ & $00-437$ & Laan 366 & & Ivory Coast \\
\hline A. ovatus Summerh. & 48 & $1.5-3.0$ & $80-402$ & Laan 205 & $6-69$ & Zaire \\
\hline \multirow[t]{2}{*}{ A. recurvus Finet } & & & $00-499$ & Veldhuizen & & \\
\hline & & & & 619, Laan 194 & $7-90$ & Ivory Coast \\
\hline A. metteniae (K raenzl.) Summerh. & 48 & $1.5-3.0$ & $80-68$ & $\begin{array}{l}\text { WALG } 101 \\
\text { Laan } 378\end{array}$ & & São Tomé \\
\hline A. species & 96 & $1.0-2.5$ & $81-326$ & & $9-61$ & Togo \\
\hline \multicolumn{7}{|l|}{ Angraecopsis } \\
\hline A. gracillima (Rolfe) Summerh. & 50 & $1.0-1.5$ & $80-527$ & Laan 418 & $9-37$ & Kenya \\
\hline A. pusilla Summerh. & so & $1.5-2.0$ & $81-386$ & Laan 455 & $9-53$ & Ruanda \\
\hline \multicolumn{7}{|l|}{ Chamaeangis } \\
\hline C. hillebrandtii (Rchb.f.) Garay & 50 & $0.7-1.5$ & $80-410$ & Laan 287 & $7-10$ & Madagascar \\
\hline C. hillebrandtii (Rchb.f.) Garay & 50 & $1.5-2.0$ & $81-459$ & Laan 485 & $10-4$ & Madagascar \\
\hline C. odoratissima (Rchb.f.) Schltr. & so & & $00-439$ & & $1-26$ & Ivory Coast \\
\hline \multirow[t]{2}{*}{ C. vesicata (Ldl.) Schltr. } & 96 & $0.5-1.5$ & $78-706$ & Laan 228 & $7-2$ & Cameroon \\
\hline & & & & Setten 326 & & \\
\hline \multicolumn{7}{|l|}{ Cyrrorchis } \\
\hline \multicolumn{7}{|l|}{ C. arcuata (Ldl.) Schltr, subsp. variabilis } \\
\hline Summerh. & 46 & $1.5-2.5$ & $00-471$ & Laan 196 & & Ivory Coast \\
\hline
\end{tabular}


Table I. (continued).

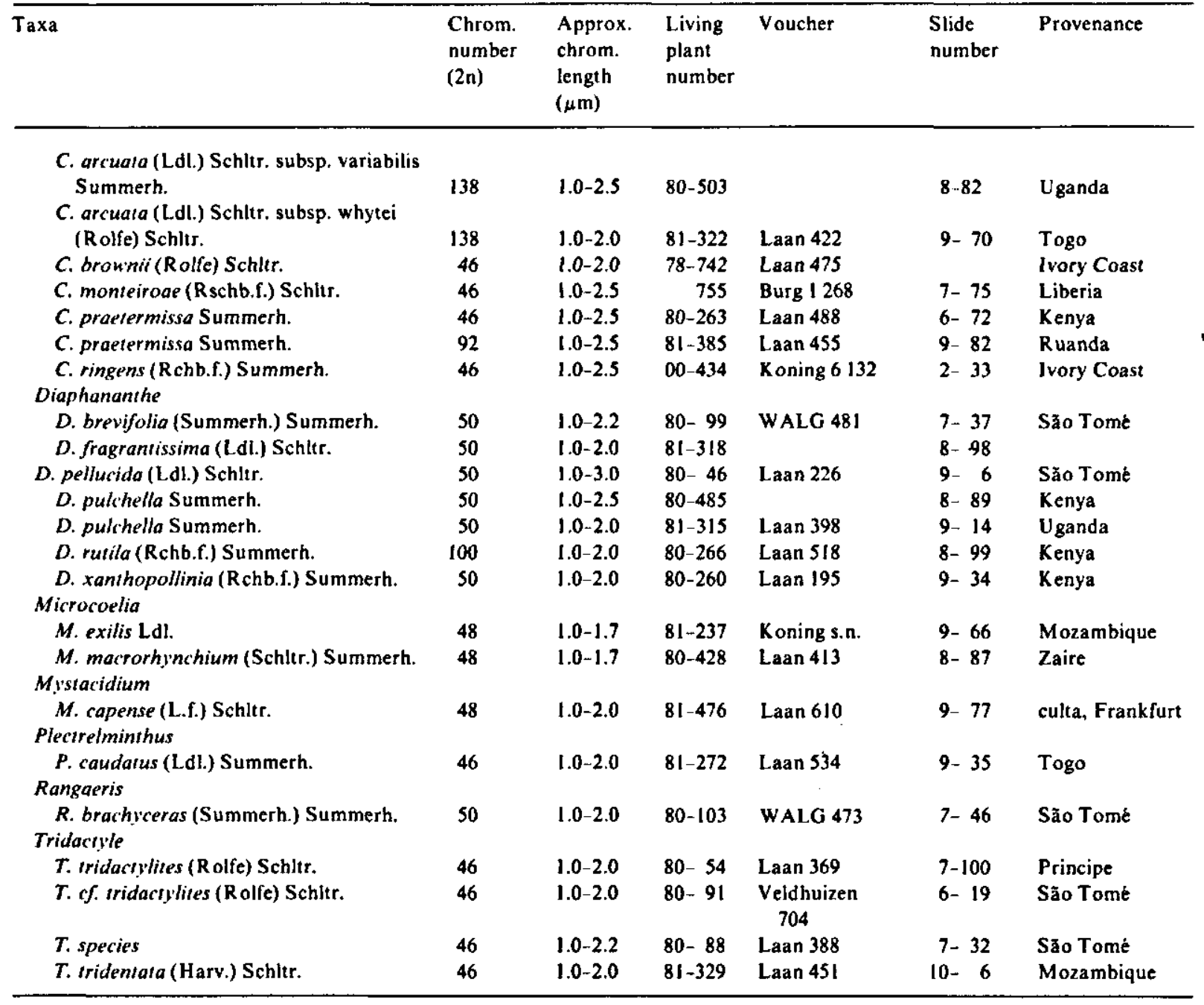

value. When the aspect of chromosome length is relevant, it will be considered in the discussion.

A number of metaphase plates could be photographed (Figs. 1-11). As can be seen from the photographs, centromeres are usually not very distinct. In general, however, the chromosomes appear to be (sub)metacentric.

Some of the chromosome counts presented in this paper are new; others corroborate records given in earlier papers (Table 2). Table 2 thus presents a survey of the chromosome numbers which have been observed so far for the "angraecoid" orchids. This survey facilitates the assessment of basic chromosome numbers (see Discussion).

It was found that the names of two species re- ferred to in our earlier paper (Arends et al., 1980) were erroneous. These are Aerangis brachycarpa (Table 1), which was presented as $A$. biloba (collection number 00-517) and $C y$ rtorchis arcuata subsp. variabilis (Table 1) which was presented as $C$. hamata (collection number 00-471).

\section{Discussion}

This section deals in particular with the assessment of basic chromosome numbers and their relevance to the taxonomy of the 'angraecoid' orchids. We realize that these basic numbers are derived from relatively small samples of the various genera, 


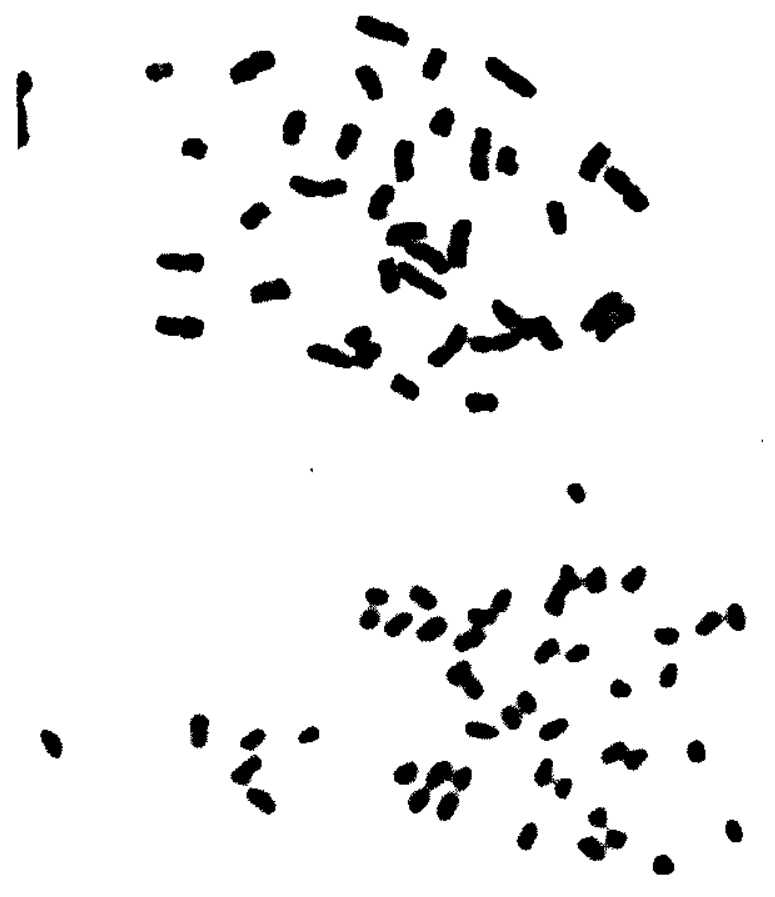

Figs. 1-2. Chromosomes in root tip cells of African monopodial orchids: (1) Angraecum leonis, $2 n=38$;- (2) Angraecum aporoides, $2 \mathrm{n}=48$. ( Ca $2000 X)$.

for at present only about $7 \%$ of the species of the Angraecinae and about $25 \%$ of the species of the Aerangidinae have been analysed. This means that the conclusions which will be drawn below might be affected by the outcome of future research.

Information about the size of the taxa was gathered from the Orchidaceae volume in the Flora of Madagascar by Perrier de la Bâthie (1941), the Floras of Africa as mentioned in the survey of Bamps (1981), the publications of Summerhayes (see the introduction to these by Redpath \& Hunt, 1972) and those of several other authors such as Garay (1973) on Angraecum, Jonsson (1981) on Microcoelia and Stewart (1979) on Aerangis of Africa. It shows that the Angraecinae appears to comprise about 14 genera with about 330 species. Within this subtribe Angraecum is the largest genus with about 200 species. Other large genera are $A e$ ranthes and Jumellea, both with about 50 species.

The Aerangidinae on the other hand comprises about 30 genera with about 260 species. Its larger genera are Aerangis (about 50 species) and Diaphananthe (about 50 species). Second in size are

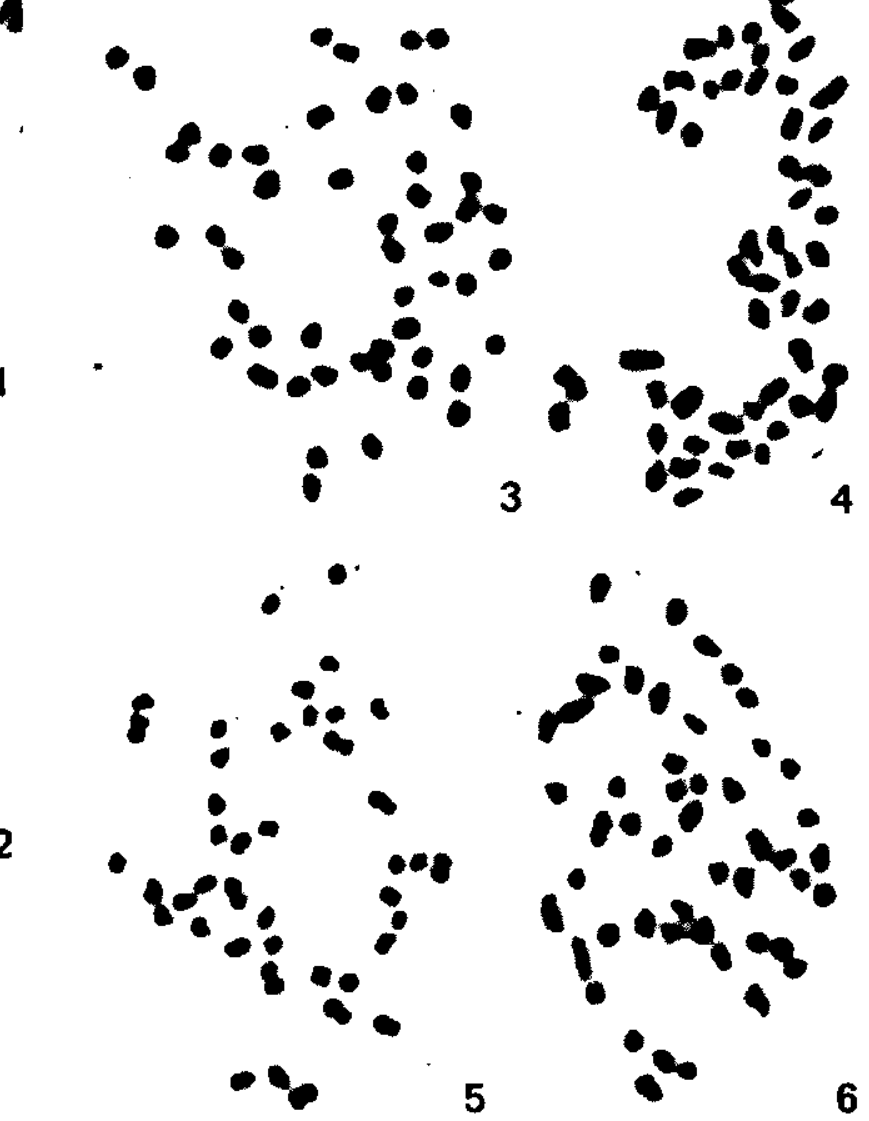

Figs. 3-6. Chromosomes in root tip cells of African monopodial orchids: (3) A erangis ugandensis, $2 \mathrm{n}=50$;- (4) Aerangis kirkii, $2 \mathrm{n}=52$; - (5) Aerangis luteo-alba var. rhodosticta. $2 \mathrm{n}=42 ;-(6)$ Aerangis citrata. $2 \mathrm{n}=50$. (Ca 2000X).

Tridactyle (about 30 species), Microcoelia (26 species), Ancistrorhynchus (about 15 species), Angraecopsis (about 15 species) and Mystacidium (about 12 species).

Most other genera of both subtribes are small (monotypic or with 2-3 species).

\section{The basic numbers}

Polyploid series in the 'angraecoid' orchids are rare, but when they occur, as for example in $C_{y} r$ torchis with $2 \mathrm{n}=46,2 \mathrm{n}=92$ and $2 \mathrm{n}=138$, it is obvious that the basic number is $x=23$. In Diaphananthe $2 n=50$ and 100 indicate $x=25$. In Ancistrorhynchus, with $2 \mathrm{n}=48,72$ and 96 , and Microcoelia with $2 n=48, x=24$ is assumed to be the lowest haploid number, since it is of the same order as the 
Table 2. Survey of chromosome numbers found in species of monopodial orchids of the African and Malagasy regions.

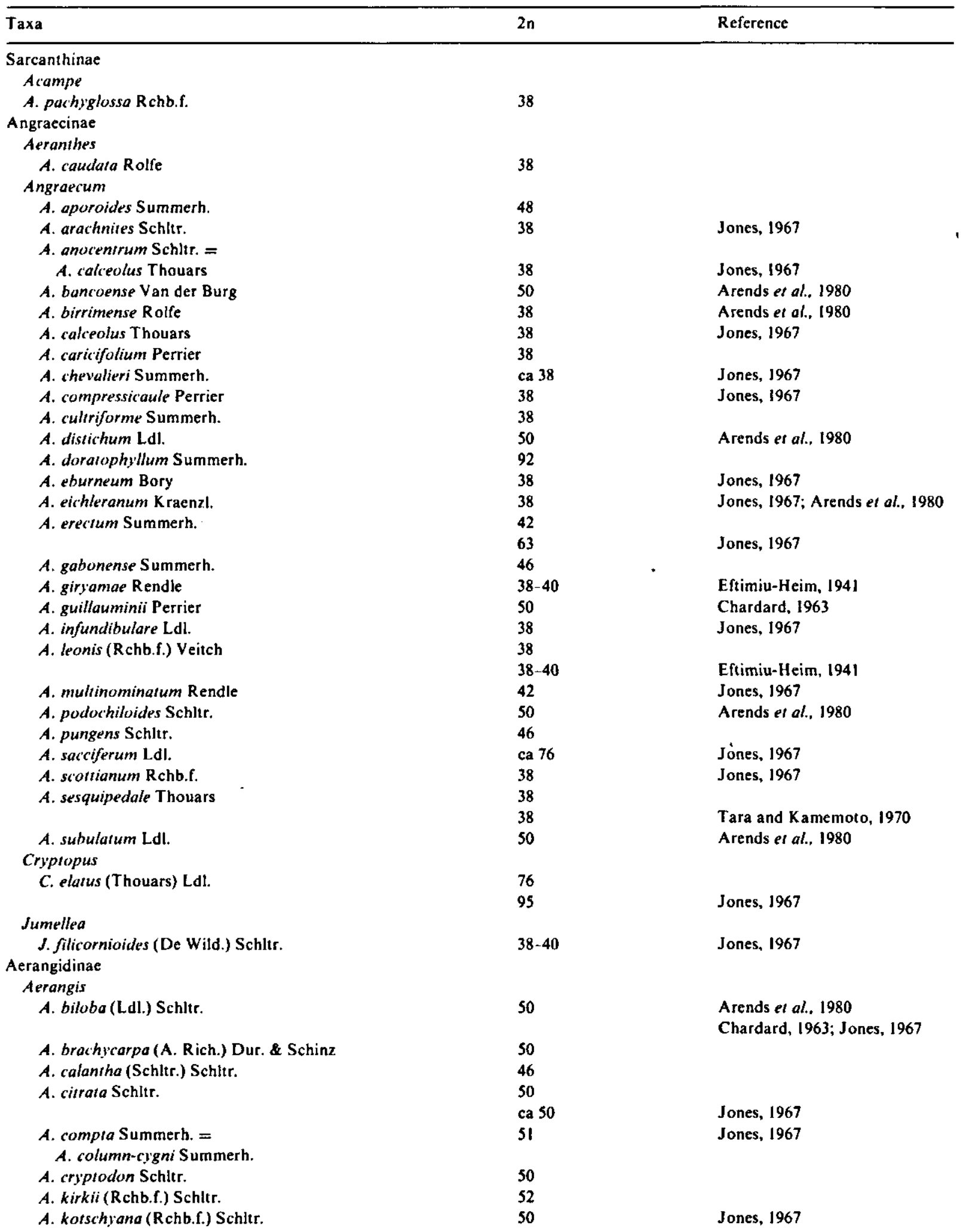


Table 2. (continued).

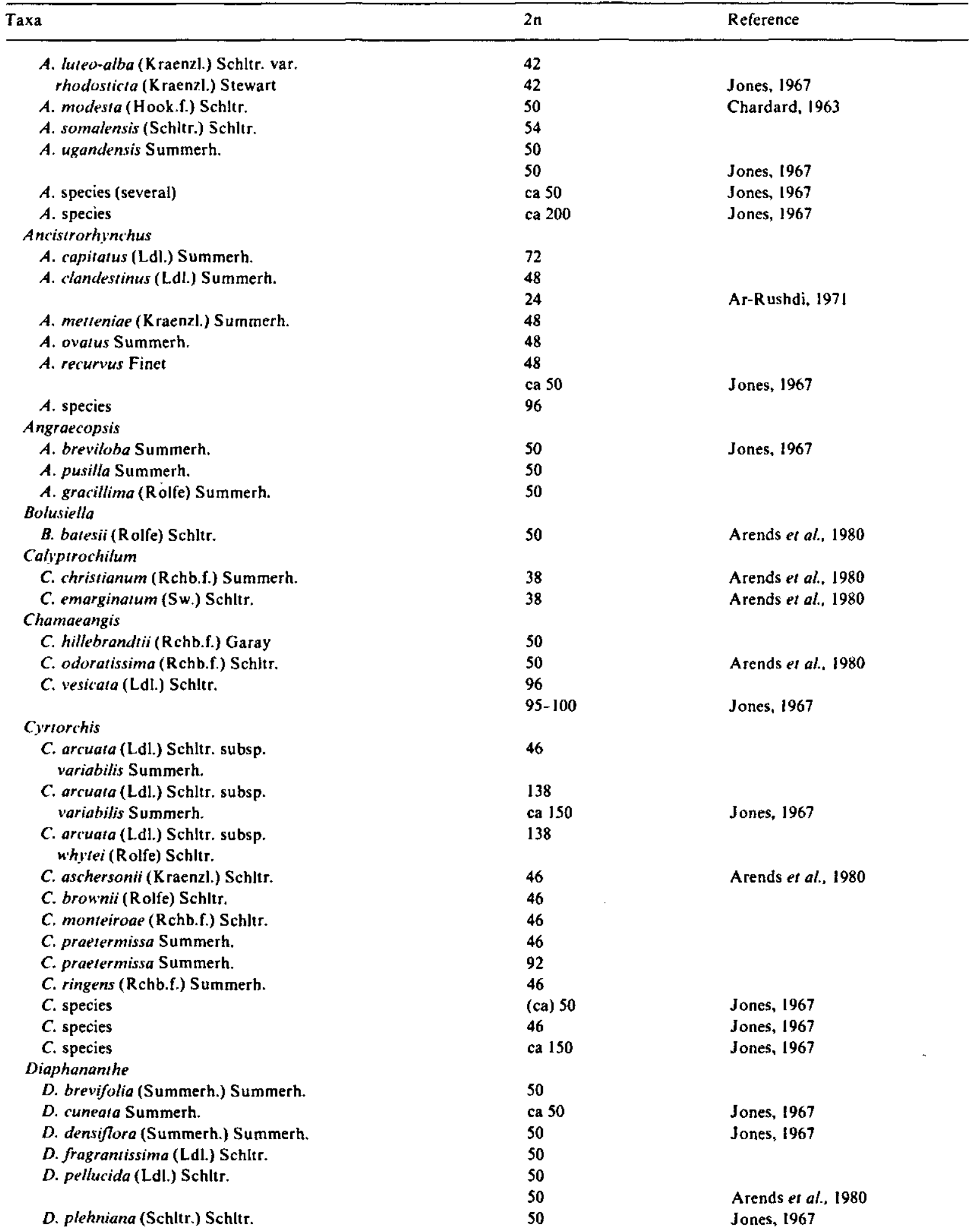


Table 2. (continued).

\begin{tabular}{|c|c|c|}
\hline Taxa & $2 n$ & Reference \\
\hline D. pulchella Summerh. & 50 & \\
\hline \multirow[t]{2}{*}{ D. rutila (Rchb.f.) Summerh. } & 100 & \\
\hline & 100 & Jones, 1967 \\
\hline D. xanihopollinia (Rchb.f.) Summerh. & 50 & \\
\hline$D$. species & ca 50 & Jones, 1967 \\
\hline \multicolumn{3}{|l|}{ Listrostachys } \\
\hline L. pertusa (Ldl.) Rehb.f. & 46 & Arends et al., 1980 \\
\hline \multicolumn{3}{|l|}{ Microcoelia } \\
\hline M. bispiculara L. Jonsson & 48 & Jonsson, 198I \\
\hline M. bulbocalcarata L. Jonsson & 48 & Jonsson, 1981 \\
\hline M. caespirosa (Rolfe) Summerh. & 47 & Arends et al., 1980 \\
\hline \multirow[t]{2}{*}{$M$. exilis Ld!. } & 48 & \\
\hline & 48 & Jonsson, 1981 \\
\hline M. gilpinae (Rchb.f. \& S. Moore) Summerh. & 48 & Jonsson, 1981 \\
\hline M. globulosa (Hochst.) L. Jonsson & 48 & Jonsson, 1981 \\
\hline M. hirschbergii Summerh. & 48 & Jonsson, 1981 \\
\hline M. koehleri (Schltr.) Summerh. & 48 & Jonsson, 1981 \\
\hline M. macrantha (H. Perr.) Summerh. & 48 & Jonsson, 1981 \\
\hline M. macrorhynchia (Summerh.) Summerh. & 48 & \\
\hline M. obovata Summerh. & 48 & Jonsson, 198I \\
\hline M. physophora (Rchb.f.) Summerh. & 48 & Jonsson, 1981 \\
\hline M. stolzii (Schltr.) Summerh. & 48 & Jonsson, 198I \\
\hline Mystacidium & & \\
\hline M. cf. capense (L.f.) Schitr. & 48 & \\
\hline \multicolumn{3}{|l|}{ Plectrelminthus } \\
\hline P. caudatus (Ldl.) Summerh. & 46 & \\
\hline \multicolumn{3}{|l|}{ Pondangis } \\
\hline P. dactyloceras (Rchb.f.) Schltr. & 46 & A rends et al.. 1980 \\
\hline \multicolumn{3}{|l|}{ Rangaeris } \\
\hline R. brachyceras (Summerh.) Summerh. & 50 & \\
\hline R. muscicola (Rehb.f.) Summerh. & ca 100 & Jones 1967 \\
\hline R. rhipsalisocia (Rchb.f.) Summerh. & 46 & A rends et al., 1980 \\
\hline \multicolumn{3}{|l|}{ Solenangis } \\
\hline S. clavata (Rolfe) Schltr. & 50 & A rends et al., 1980 \\
\hline S. scandens (Schltr.) Schltr. & 50 & Arends et al. 1980 \\
\hline \multicolumn{3}{|l|}{ Tridactyle } \\
\hline T. anthomaniaca (Rchb.f.) Summerh. & ca 100 & Jones, 1967 \\
\hline$T$. tridactylites (Rolfe) Schltr. & 46 & \\
\hline T. tridentasa (Harv.) Schltr. & 46 & \\
\hline$T$. species & ca 50 & Jones, 1967 \\
\hline
\end{tabular}

basic numbers $x=23$ and 25 found in other taxa in the group.

From the chromosome numbers presented in Table 2 the following basic numbers result:

\section{Sarcanthinae}

$\begin{array}{ll}\begin{array}{c}\text { Acampe } \\ \text { Angraecinae }\end{array} & \mathrm{x}=19 \\ \text { Aeranthes } & \mathrm{x}=19 \\ \text { Angraecum } & \mathrm{x}=19,21,24,25 \\ \text { Cryptopus } & \mathrm{x}=19\end{array}$

Jumellea

Aerangidinae

Aerangis

Ancistrorhynchus

Angraecopsis

Calyptrochilum

Chamaeangis

Cyrtorchis

Diaphananthe

Listrostachys

Microcoelia

$$
x=19
$$$$
x=21,23,25,26,27
$$$$
x=24
$$$$
x=25
$$$$
x=19
$$$$
x=24,25
$$

$x=23$

$x=25$

$x=23$

$x=24$ 

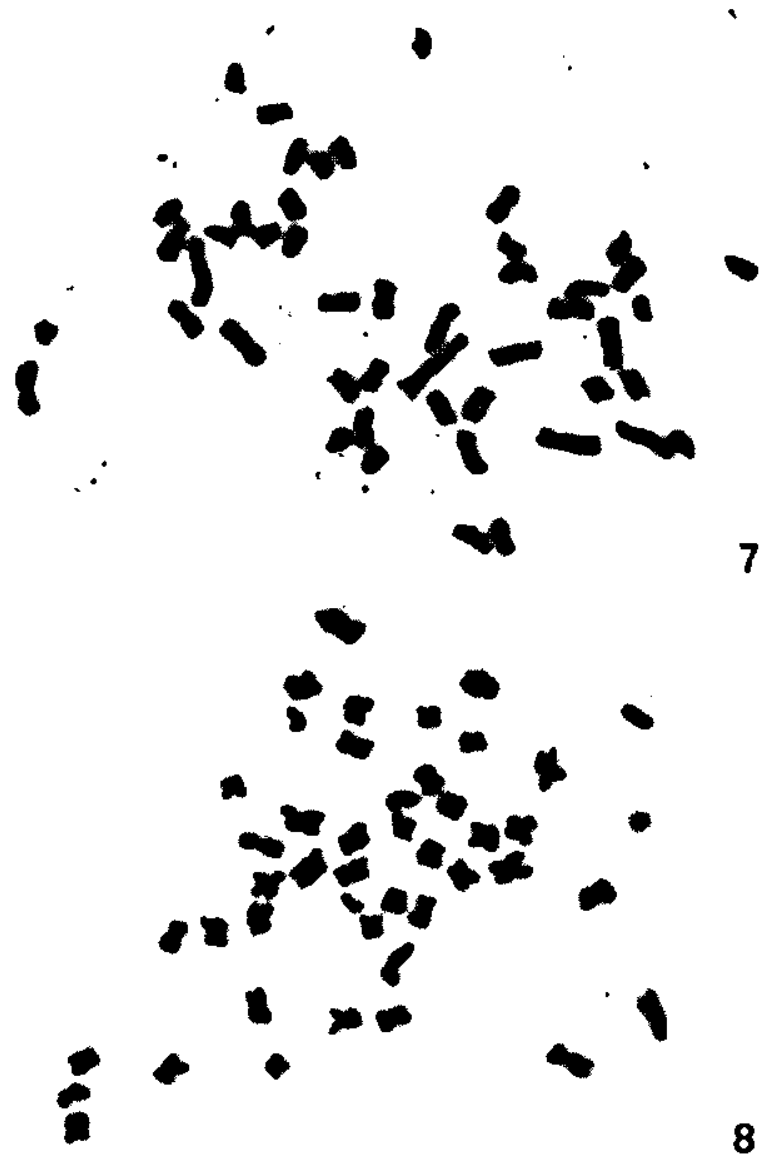

8

Figs. 7-8. Chromosomes in root tip cells of African monopodial orchids: (7) Ancistrorhynchus ovatus, $2 \mathrm{n}=48$; - (8) Cyrtorchis praetermissa. $2 \mathrm{n}=46$. (Ca $2000 \times)$.

$\begin{array}{ll}\text { Mystacidium } & \mathrm{x}=24 \\ \text { Plectrelminthus } & \mathrm{x}=23 \\ \text { Podangis } & \mathrm{x}=23 \\ \text { Rangaeris } & \mathrm{x}=23,25 \\ \text { Solenangis } & \mathrm{x}=25 \\ \text { Tridactyle } & \mathrm{x}=23\end{array}$

\section{Basic numbers and their occurrence in the subtribes}

According to the subtribes in which the various basic numbers are found the following comments can be made.

Angraecinae: the finding of $2 \mathrm{n}=38$ in one species of Aeranthes and Jumellea respectively yields some evidence that these genera have a basic number of $x$ $=19$. Likewise Cryptopus, a small genus with perhaps three species, appears to be characterized by $x$ $=19$. One of its species, $C$. elatus apparently is a
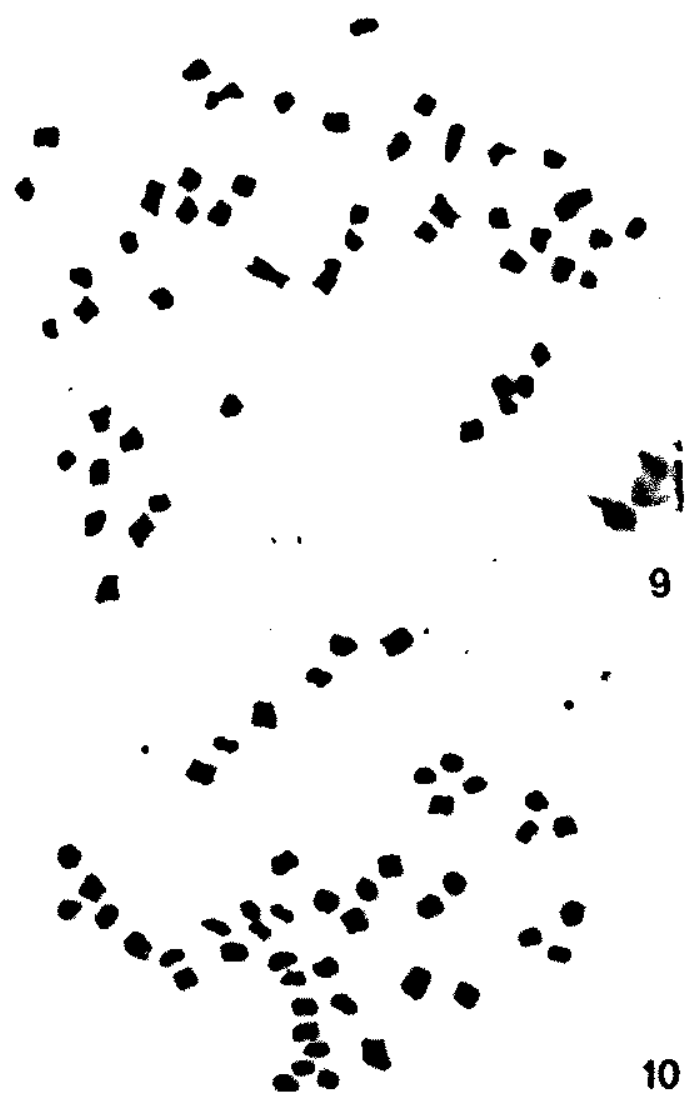

10

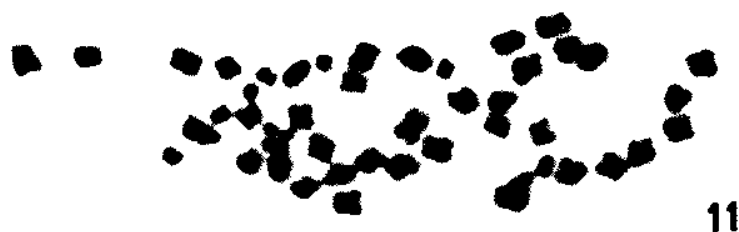

Figs. 9- $/ 1$. Chromosomes in root tip cells of African monopodial orchids: (9) Diaphanonthe brevifolia. $2 \mathrm{n}=50$;- (10) Microcoelia exilis, $2 \mathrm{n}=48$; (I1) Tridactyle tridactylites, $2 \mathrm{n}=46$. (Ca 2000X).

polyploid taxon with several cytotypes since Jones (1967) found a pentaploid $(2 n=95)$ and the present authors a tetraploid $(2 \mathrm{n}=76)$ chromosome number.

In Angraecum, the major genus in the Angraecinae, the chromosome numbers of twenty-six species are known. Of these, thirteen have $2 n=38$ and one $2 n=76(x=19)$.

So far the evidence accumulated for the abovementioned taxa is in accordance with the conclusions of Summerhayes (1966) and Jones (1967) that the subtribe Angraecinae is characterized by $x=19$. 
However, consideration of the chromosome numbers of the remainder of the analysed species of Angraecum disagrees with their conclusion. The basic numbers in this group of Angraecum are variable. They range from $\mathrm{x}=21$ (from $2 \mathrm{n}=42$ in $A$. multinominatum and $2 \mathrm{n}=42 / 63$ in $A$. erectum), to $\mathrm{x}=23$ (from $2 n=46$ in $A$. gabonense and $A$. pungens and $2 \mathrm{n}=92$ in $A$. doratophyllum), $\mathrm{x}=24$ (from $2 \mathrm{n}=48$ in $A$. aporoides) and $\mathrm{x}=25$ (from $2 \mathrm{n}$ $=50$ in $A$. bancoense, $A$. distichum, A. guillauminii, $A$. podochiloides and $A$. subulatum).

Aerangidinae: except for the puzzling case of Calyptrochilum (a genus with an elongated rostellum, the key character of the subtribe Aerangidinae) with $x=19$, all genera of this subtribe have basic numbers which are higher than $x=19$, i.e. $x=$ $23,24,25,26$ and 27 , those of $x=23,24$ and 25 being the most frequent. Most of the genera exclusively have one of these numbers.

As far as present knowledge permits it can be concluded that the larger genera such as Ancistrorhynchus, Cyrtorchis, Diaphananthe and Microcoelia have euploid numbers only. In Aerangis, however, aneuploidy appears to be frequent. Chamaeangis vesicata likewise is an aneuploid taxon, instead of the expected $2 n=100$ its chromosome number is $2 n=96$ (i.e. $4 x-4$ ). Rangaeris is a genus which is, from a taxonomist's point of view, rather heterogeneous (Summerhayes, 1936); the finding of $2 n=46$ in one of its species and $2 n=50 / 100$ in the other two species shows that a similar heterogeneity is found in its chromosome number.

In conclusion it appears that the Aerangidinae is predominantly characterized by the numbers of $\mathrm{x}=$ 23,24 and 25. The position of Calyptrochilum with $x=19$ within this subtribe has to be reconsidered.

The Angraecinae, however, appears to be divisible into two groups according to basic number. The first group, with $\mathrm{x}=19$, comprises Aeranthes, Jumellea, Cryptopus and a group of species of Angraecum. The second group comprises the species of Angraecum in which basic numbers of $\mathrm{x}=21,24$ and 25 occur.

The correlation between rostellum shape and basic numbers, the evolution of different basic numbers

The diagnosis of the Angraecinae and the Aerangidinae of Summerhayes (1966) states that there exists a discontinuity between the two subtribes in respect to rostellum shape as well as in respect to basic chromosome number. According to Jones (1967) the discovery of two basic numbers, i.e. $x=$ 19 for the Angraecinae and $x=25$ for the Aerangidinae reflects a fundamental difference between the two subtribes.

In the light of the present knowledge of chromosome numbers of the species of the Aerangidinae, it is clear that the subtribe is characterized by several basic numbers higher than $x=19$. The numbers are $x=23,24,25,26$ and 27 , of which $x=23,24$ and 25 are the most frequent. This implies that the original circumscription of the Aerangidinae - in short: monopodial orchids with an elongated rostellum and a basic number of $x=25$ - could be rewritten as 'monopodial orchids with an elongated rostellum and basic number of $x=23,24,25$ and higher'. The finding of $2 n=38$ and hence $x=19$ for Calyptrochilum however, would not fit such a proposal. The flowers of this genus have a distinctly elongated rostellum. Nevertheless the position of the genus has apparently been of some concern to taxonomists. Schlechter (1925) remarked that the flowers of Calyptrochilum are reminiscent of those of $A n$ graecum, but deviate by the presence of a rostellum.

The circumscription of the other subtribe, the Angraecinae - in short: monopodial orchids with a short rostellum and a basic number of $x=19$ cannot be maintained. Its genera Aeranthes, Jumellea, Cryptopus and part of Angraecum indeed have $\mathrm{x}=19$, but the other part of Angraecum is characterized by the higher basic numbers of $x=21,23,24$ and 25 .

It is concluded that Jones' (1967) correlation between the presence or absence of a rostellum on the one hand and a particular basic number on the other, breaks down. All evidence points to the possibility that the rostellum character for separating the 'angraecoid' species has been given too much weight.

The 'fundamental difference' between the basic numbers of $x=19$ and $x=25$ as was stated by Jones (1967) suggests two independent lines of evolution within the group of the 'angraecoid' orchids. It is now obvious that the gap between these two basic numbers has been narrowed by our finding the numbers $x=21,23$ and 24 . Until now evidence is lacking that the number of $x=20$ occurs within the 'angraecoid' orchids. Records of $2 n=40$ for this group in earlier literature have proved to be errone- 
ous. F. G. Brieger (in Schlechter, 1974, page 101) points to the fact that the haploid number of $x=20$ is quite frequent in the Orchidaceae. He considers this number as a starting point for the evolution of close numbers such as $x=19$ and 21 .

When this assumption is applied to the angraecoid' orchids it would mean that a group of species with $x=19$ evolved independently of another group of species with basic numbers of $x=21$ and higher after early divergence. About the ancestral taxon (or taxa), putatively with $x=20$, there is no certainty: Dressler (1981) states that it is possible that the Vandeae (i.e. the tribe comprising the Aerangidinae, Angraecinae and Sarcanthinae) does not have any close living relatives.

\section{Basic numbers and taxonomy}

Similar basic numbers in related groups can throw light upon their position with regard to each other. Jonsson (1981) in his exemplary revision of Microcoelia concluded that this genus, with $\mathrm{x}=24$, has an isolated position within the Aerangidinae, which is also indicated by difficulties in relating the genus to many others on morphological grounds. He suggested, apparently on the basis of morphological similarities, that Chauliodon. Margelliantha and $M y$ stacidium should be investigated for their chromosome numbers. Indeed Mystacidium appears to have a basic number of $x=24$ (Table 1), which could place it near Microcoelia.

When Ancistrorhynchus, also with a basic number of $x=24$, is considered however, it is in our opinion obvious that this genus is less closely related to Microcoelia and Mystacidium than e.g. to Cyrtorchis $(\mathrm{x}=23)$. The karyotype of Ancistrorhynchus (Fig. 7) with the longest chromosomes observed so far in the 'angraecoid' orchids, is distinctly different from that of any other genus in the Aerangidinae.

It is noted that in the literature, except for the suggestion by Jonsson (1981) about the relationship of Microcoelia, further suggestions concerning the position of the other genera do not occur. Conclusions about relationships, when exclusively based on chromosome numbers, would certainly be erroneous in several instances. Such conclusions cannot be compared with suggestions or conclusions obtained from (macro)morphological observations, as the latter are lacking at present. The authors can only venture to postulate that the genera Cyrtorchis, Listrostachy', Plectrelminthus, Podangis and Tridactyle, all with $\mathrm{x}=23$ and a similar karyotype with chromosomes of an intermediate length (Figs. 8 and 11 ), have a related position within the Aerangidinae. It does not seem appropriate, however, to include any species with $2 \mathrm{n}=$ 46, as e.g. Aerangis calantha, in this group. Its vegetative appearance and floral morphology as well as its karyotype with short chromosomes would oppose such a decision.

In his diagnosis, Summerhayes (1966) divided the 'angraecoid' orchids into the Angraecinae and the Aerangidinae on the basis of rostellum shape. As he coined a correlation between rostellum shape and basic number (short rostellum / $x=19$ versus elongated rostellum / $x=25$ ) he attributed equal weight to both characters in distinguishing the subtribes. When the principle of giving equal weight to rostellum shape and basic number is applied in the present situation of knowledge of chromosome numbers, four groups result. They are:

Group 1: Aeranthes, Jumellea, Cryptopus and part of Angraecum (short rostellum / x = 19)

Group 2: the remainder of Angraecum (short rostellum / $x=21,23,24$ and 25)

Group 3: Calyptrochilum (elongated rostellum/ $\mathrm{x}=19$ )

Group 4: Aerangis, Ancistrorhynchus, Bolusiella, Angraecopsis, Chamaeangis, Cyrtorchis, Diaphananthe, Listrostachys, Microcoelia, Mystacidium, Plectrelminthus, Podangis, Rangaeris, Solenangis and Tridactyle (elongated rostellum / $\mathrm{x}=23,24$, 25,26 and 27).

The character combinations in groups 1 and 4 are similar to the combinations defined by Summerhayes (1966), although the circumscription of the basic number characteristic of group 4 should be changed from $x=25$ to $x=23$ to 27 . The character combinations in groups 2 and 3 are new.

The division presented here would suggest the introduction of two additional taxonomic groups at the subtribe level, but we do not advocate such a procedure. Further evidence from cytology and macromorphology is needed, and data from e.g. anatomy, pollen morphology and chemotaxonomy should also be considered.

In the preceding part of this discussion it was suggested that the evolution of a basic number of $x$ 

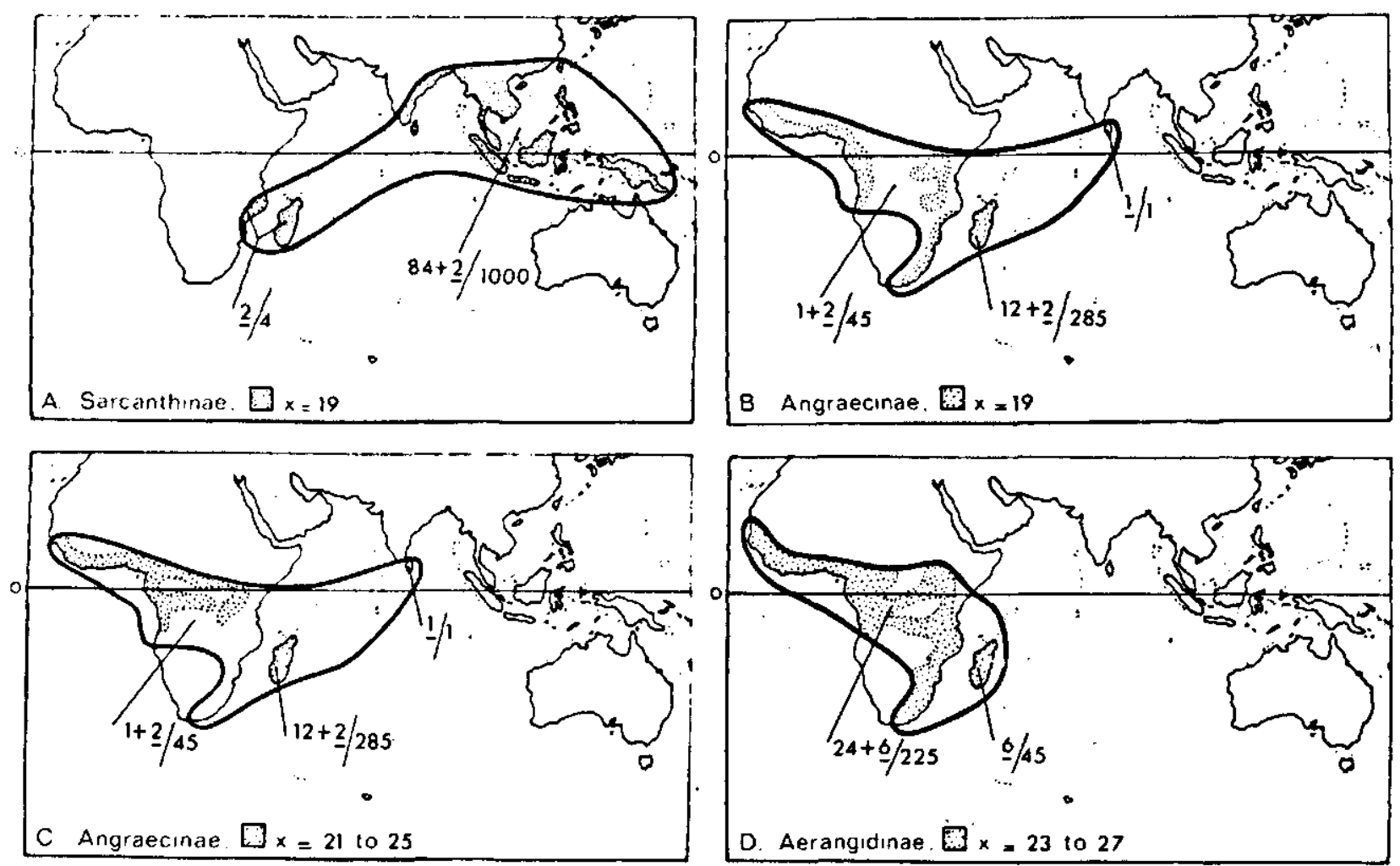

Fig. 12. Distribution of the subtribes Sarcanthinae, Angraecinae and Aerangidinae (solid lines). The figures in the maps indicate approximate numbers of genera and species respectively. The numbers of genera with a disjunct distribution, i.e. the genera represented in two or three different floras (African, Malagasy and Asian/Australasian), are underlined. The shaded areas indicate the occurrence of the particular basic chromosome number (groups). For the Sarcanthinae the base number is assessed from the chromosome numbers as given in Withner (1974), for the Angraecinae and the Aerangidinae from the chromosome numbers of the species as presently analyzed (Table 2). When the chromosome number of a species is known from a single sample (e.g. Acampe pachyglossa, $2 \mathrm{n}=38 ; \mathrm{x}=19$, Mozambique) it is assumed that this number applies to the species in its complete area of distribution (in the case of $A$. pachyglossa Madagascar and Africa appr. opposite Madagascar).

$=19$ from $x=20$ is opposed to the evolution of a group of basic numbers of $x=21$ and higher. The foregoing division implies, however, that the evolution of these opposing groups of basic numbers would have occurred in taxa with a short rostellum as well as in taxa with an elongated rostellum. Of course one could also consider the alternative that the evolution of a short versus an elongated rostellum could have occurred in the two opposing groups according to basic number. This leaves us with the question about primitive and advanced conditions in this group of orchids. At present there are no answers: Dressler (1981) remarks about the Vandeae, to which the 'angraecoid' orchids belong, 'that it is not at all clear what is the primitive flower for this tribe, and it is thus difficult to delineate trends'.
Within the genus Angraecum, which has been divided into 19 sections (see Garay, 1973) various basic numbers occur. In some of these sections the chromosome number is known of more than one species e.g. section Dolabrifolia ( $A$. aporoides, $2 \mathrm{n}$ $=48 ; A$. bancoense, $2 \mathrm{n}=50 ; A$. distichum, $2 \mathrm{n}=50$ and $A$. podochiloides, $2 \mathrm{n}=50$ ); section Pectinaria (A. doratophyllum. $2 \mathrm{n}=92 ;$ A. gabonense, $2 \mathrm{n}=$ 46; $A$. pungens, $2 \mathrm{n}=46$ and $A$. subulatum, $2 \mathrm{n}=$ 50); section Gomphocentrum ( $A$. calceolus, $2 \mathrm{n}=38$ and $A$. guillauminii, $2 \mathrm{n}=50$ ) and section Angraecum ( $A$. eburneum, $2 \mathrm{n}=38 ; A$. giryamae, $2 \mathrm{n}=38$ and $A$. sesquipedale, $2 \mathrm{n}=38$ ). Hence it appears that, except for the section Gomphocentrum $(2 \mathrm{n}=$ 38 and 50 ), the sections are characterized by similar basic numbers. Further evidence is necessary in order to see whether this also applies to the other sections. 


\section{Cytogeography}

In spite of the proposal by Jones (1967) to distinguish five subtribes within the tribe Vandeae Lindley, which comprises exclusively monopodial orchids, Dressler (1981) recognized three subtribes. They are: Sarcanthinae Bentham, Angraecinae Summerhayes and Aerangidinae Summerhayes. We adhere to Dressler's view, as Jones failed to stipulate how the two additional subtribes, Vandinae and Aeridinae, could be separated from the Sarcanthinae.

The Sarcanthinae is distributed in Asia-Australasia, but two of its genera, Acampe and Taeniophyllum, have a disjunct distribution, as one or two of their species occur in eastern Africa and Madagascar (Dressler, 1981; Perrier, 1941).

The Angraecinae is found on Madagascar, the Mascarenes and to a lesser extent on the Comores. The remainder of the group (about $15 \%$ of the number of species) occurs in continental Africa. Dressler (1981) mentions that the subtribe is represented in Asia by one species (Angraecum zeylanicum of Sri Lanka), and also by a few small genera such as Campylocentrum in the Americas.

The Aerangidinae, on the contrary, is mainly found on the continent of Africa, although 15\% of its species occur principally in the Malagasy area.

All genera of the Sarcanthinae, which represent the Asian monopodial orchids, are characterized by a basic number of $x=19$, as can be concluded from the chromosome number survey of Tanaka and Kamemota in Withner (1974). The African representative of the Sarcanthinae, i.e. Acampe pachyglossa (Eastern Africa and Madagascar) likewise has $x=19$ (from $2 n=38$, Table 1). Distribution of the Sarcanthinae is presented in Figure 12A.

The Angraecinae has its main distribution in the Malagasy area. This pertains in particular to Aeranthes, Jumellea and Cryptopus (Stewart, 1980). These genera are characterized, as was already assumed on the basis of the present evidence, by a basic number of $x=19$. The bulk of evidence about the chromosome numbers in the Angraecinae applies to Angraecum, by far the largest genus in the subtribe. As was shown before, this can be divided into two groups, one with a basic number of $x=19$ and the other with numbers ranging from $x=21$ to 25.

Of the twenty-six species analysed to date ( $\mathrm{Ta}$ - ble 2) nine ( $A$. arachnites, $A$. calceolus, $A$. caricifolium, A. compressicaule, A. eburneum, A. guillauminii, A. leonis, $A$. scottianum and $A$. sesquipedale) are endemics of Madagascar. Except for $A$. guillauminii $(2 \mathrm{n}=50)$ their chromosome number is $2 \mathrm{n}=38$.

Of the other species with a basic number of $\mathrm{x}=$ 19, $A$. birrimense, $A$. chevalieri, $A$. eichleranum and $A$. infundibulare, all with $2 \mathrm{n}=38$, occur in the Guineo-Congolian Region (White, 1979), whereas $A$. cultriforme, A. giryamae, $A$. chevalieri and $A$. infundibulare also with $2 \mathrm{n}=38$ occur in Eastern Africa. The last species of the $\mathrm{x}=19$ group, $A$. sacciferum $(2 \mathrm{n}=$ ca 76$)$, is widely distributed in tropical Africa. The distribution of the above is shown in Figure 12B.

Of the species with higher basic numbers, only A. erectum $(2 n=42)$ occurs in Eastern Africa. The remaining species of this group, i.e. $A$. aporoides $(2 \mathrm{n}=48)$, A. bancoense $(2 \mathrm{n}=50)$, A. distichum $(2 \mathrm{n}$ $=50), A$. doratophyllum $(2 \mathrm{n}=92), A$. gabonense $(2 \mathrm{n}=46)$, A. multinominatum $(2 \mathrm{n}=42)$, A. podochiloides $(2 \mathrm{n}=50), A$. pungens $(2 \mathrm{n}=46)$ and $A$. subulatum $(2 \mathrm{n}=50)$ are all found in the GuineoCongolian Region, although $\boldsymbol{A}$. distichum extends its occurrence east- and southwards. These distributions are shown in Figure 12C.

The Aerangidinae, the second subtribe of the 'angraecoid' orchids, is characterized by basic numbers ranging from $x=23$ to $x=27$. Most genera of the Aerangidinae are confined to Continental Africa, but some species of Aerangis, Chamaeangis, Microcoelia and Solenangis occur on Madagascar as well. The chromosome numbers of the Malagasy species of Aerangis and Microcoelia (Johnsson, 1981) are similar to the numbers of their African counterparts. Distribution of the Aerangidinae is shown in Figure 12D.

The maps presented in Figures $12 \mathrm{~A}$ and $\mathrm{B}$, which show the distribution of taxa with $\mathrm{x}=19$, corroborate the statement of Good (1974, page 272) that the flora of Madagascar has remarkable relationships with the floras of Asia and Australasia. The occurrence of some taxa with $\mathrm{x}=19$, in particular in the Guineo-Congolian Region, shows that there is a relationship with the flora of the African continent as well, although to a lesser degree. This minor affinity between the floras of Madagascar and Africa is again demonstrated by the maps in Figures $12 \mathrm{C}$ and $\mathrm{D}$; taxa with high basic numbers $(\mathrm{x}=21$ to 
27) are a minority of Madagascar, whereas they are frequent in Africa.

The geography of apparently related plant groups often yields valuable information concerning their mutual relationships. The generally accepted affinity between the flora of Madagascar on the one hand and those of Asia and Australasia on the other, together with the common number of $x=$ 19 for the monopodial orchids of these floras, presents a challenge to the taxonomy of these orchids. The present system implies that the taxa with $x=19$ of the Angraecinae have a closer affinity to the taxa with $x=21$ to 25 within the same subtribe than with the Asian Sarcanthinae having $x=19$.

\section{Acknowledgements}

Professor J. Sybenga (Department of Genetics, Agricultural University, Wageningen), Ir. W. G. van der Burg (Government Seed Testing Station, Wageningen), Professor H. C. D. de Wit and Dr. J. J. F. E. de Wilde (both Department of Plant Taxonomy and Plant Geography, Wageningen) contributed by critically reading the initial manuscript. Their remarks and suggestions are gratefully acknowledged. As usual Mrs Judith van Medenbach de Rooy-Ronkel meticulously prepared the typescript. Miss Erica van Dijk showed her ability in handling the microscope while participating in the project as a trainee. Miss Ike Zewald kindly assisted in the preparation of the maps.

\section{References}

Arends, J. C., Van der Burg, W. J.\& Van der Laan, F. M., 1980. Notes on african orchids. Liber gratulatorius H. C. D. de Wit, Miscell. Pap. 19 (1980), Landbouwhogeschool Wageningen.
Ar-Rushdi, A. H., 1971. Chromosomes of some West African orchids. Cytologia 36: 487-492.

Bamps, P., 1981. Répertoire des familles de phanerogames traitees dans les principales flores de l'Afrique tropicale. Jard. Bot. Nat. Belgique, Meise.

Chardard, R., 1963. Contribution a l'étude cytotaxonomique des Orchidées. Revue Cytol. Biol. vég. 26: 1-58.

Dressler, R. L., 198I. The orchids, natural hist ory and classification, Harvard Univ. Press, Cambridge.

Eftimiu-Heim, P., 1941. Recherches sur les noyaux des Orchidées. Botaniste 31: 65-111.

Garay, L. A., 1973. Systematics of the genus Angraecum (Orchidaceae). Kew Bull. 28: 495-516.

Good, R., 1974. The geography of the flowering plants. Longman, London.

Jones, K., 1967. The chromosomes of orchids, II Vandeae Lindl. Kew Bull. 21: 15!-156.

Jonsson, L., 1981. A monograph of the genus Microcoelia (Orchidaceae). Symb. bot. upsal. 23: 4.

Perrier de la Bâthie, H., 1941. Orchidées, 1. 11. In: Flore de Madagascar (ed. H. Humbert). Tananarive. Impr. Offic.

Redpath, J. \& Hunt, P. F., 1972. Index to African Orchids I-XXX' by V.S. Summerhayes. Kew Bull. 27: 337-369.

Schlechter, R., 1918. Versuch einer natülichen Neuordnung der afrikanischen angraekoiden Orchidaceen. Beih. bot. Zbl. 36: 62-181.

Schlechter, R., 1925. Die Orchideen. Parey, Berlin.

Schlechter, R., 1926. Das System der Orchidaceen. Notizbl, Bot. Gart. Berlin. Dahlem 9: 590 591.

Schlechter, R., 1974. Die Orchideen, 3rd ed. (Brieger, F. G., Maatsch, R.\& Senghas, K., eds.). Parey, Berlin \& Hamburg.

Stewart, J., 1979. A revision of the African species of Aerangis. Kew Bult. 34: 239-319.

Stewart, J., 1980. The angraecoid orchids of the African region. Am. Orch. Soc. Bull. 49: 621-629.

Summerhayes, V.S., 1936. Rangaeris Summerh. gen. nov. Bulf. misc. Inf. R. bot. Gdns Kew 1936: 227.

Summerhayes, V.S., 1966. African orchids: XXX. Kew Bull. 20: 188.

Tara, M. \& Kamemoto, H., 1970. Karyotype relationships in the Sarcanthinae (Orchidaceac). Am. J. Bot. 57: 176-182.

White, F., 1979. The Guineo-Congolian Region and its relationships to other phytochoria. Bull. Jard. Bot. nat. Belg. 49: I1-55.

Withner, C., 1974. The orchids. Scientific Studies, Wiley, New York.

Received 10.1.1983 Accepted 23.6.1983. 